\title{
Leadership in Fury Movie Directed by David Ayer
}

\author{
Unpris Yastanti', Virky Septian Dwi Putra² \\ Universitas Bina Sarana Informatika \\ Email: unprisyastanti@gmail.com
}

\section{E-ISSN : 2579-4574 P-ISSN : 2549-7359}

\begin{abstract}
The purpose of this study is to identify leadership in Fury movie directed by David Ayer. This study used descriptive qualitative approach. The result of this study: (1). The main character is the leader of his team. He makes a strategy and he tells the strategy to his team. (2) Leadership style of the main character in the Fury movie are autocratic and bureaucratic leadership style. (3) The moral message in the movie are a virtue, sacrifice and religious man in doing their task in the battlefield.
\end{abstract}

Keywords: Leadership, Fury Movie, Semiotics, David Ayer

\section{https://ojs.unm.ac.id/eralingua}

\section{INTRODUCTION}

The movie is an electronic signal of moving graphics pictures, or text used to combine a steady stream of images used for entertainment, education, or other uses. This term is often used to describe content that is longer than ten minutes or something viewers would watch on TV or at the theatre (Anisti, 2017). Movie is one of entertainments, and it has been one of research objects which have been conducted by many researchers (Ning \& Xia, 2018; Thorbjørnsen et all., 2019; Kim et all., 2018). Movie "Fury" tells the story of the leader from the main character that has a good leadership in his team member in the soldier. In this movie, the writer finds leadership acts from the main character in an army squad in an atmosphere of war. In this case, the leadership for a team member is an important role to achieve the goals. Leadership can be the theme of discussion in literature because leadership is an element contained in a movie as submitted by Achua and Lussier (2010) defines that leadership is the influencing process of leaders and followers to achieve organizational objectives through change. As it is supported by $\mathrm{HaO}$ and Rashad, 2015; Feriyanto and Triana, 2015; Sharma,2013; and Iqbal et al,2015. Furthermore, leadership is an individual ability to lead and direct a group of people in order to achieve certain goals (Semuel et al., 2017).

Dunne in Yastanti and Soraya (2016) assume that the main character is scenic objective. A dramatic scene typically centers on one character pursuing one overriding scenic objective and encountering obstacles that make it difficult to achieve. The theory tells that the main character is the scenic object that has some 
trouble and it is hard to achieve and the main character has conflict between main characters to further concentrate dramatic attention (Wallin and Arjunan, 2011)

The main character in Fury movie is Wardaddy. He leads the tank to capture a small German town. This movie is about at the end of World War II, where the Allies almost defeated the Nazi army of Germany. Sergeant Wardaddy's allied forces had a very dangerous last mission. Sergeant Wardaddy brought his men to carry a Sherman tank named "Fury" to attack the remains of Nazi soldiers in the heart of Germany. The writer is interested to analyse the movie because the movie "Fury" is one of the box office success movies in 2014. It is directed by David Ayer. The film grossed $\$ 85.8$ million in North America and $\$ 126$ million in other territories for a worldwide total of $\$ 211.8$ million, against a budget of $\$ 68$ million. This movie also wins 3 nominations award namely are Hollywood Film Award, National Board of Review and Santa Barbara International Film Festival. This movie contains a lot of leadership message from the main character or people around the main character. The movie gives some spirit and suggestion for a reviewer to how being a good leader for the writers or other people in real life no matter in a good or bad situation to achieve the goal.

\section{RESEARCH METHOD}

The writers used qualitative method to analyze the data. The data are scenes and dialogues in Fury movie. The writer takes some theories from books, sites, journal and references from various other writers to assist the writer in order to arrange the paper. The writer also collects some data information through e-books and libraries. The researcher is a key instrument, sampling the source of data is done using purposive and snowball, with triangulation of data collection techniques (combined), data analysis is inductive or qualitative and the result of qualitative research emphasized meaning rather than generalization (Sugiyono,2010).

\section{RESULT AND DISCUSSION}

\section{The Leadership Shows of the Main Character}

Leadership is the activity of leading a group of people or an organization or the ability to do a certain job. In this movie, the leadership came from the main character gives the impression that the influence for a people action and the act of inspiring the members to perform and engage in achieving a goal. Here are some scenes that show the main character leadership. 


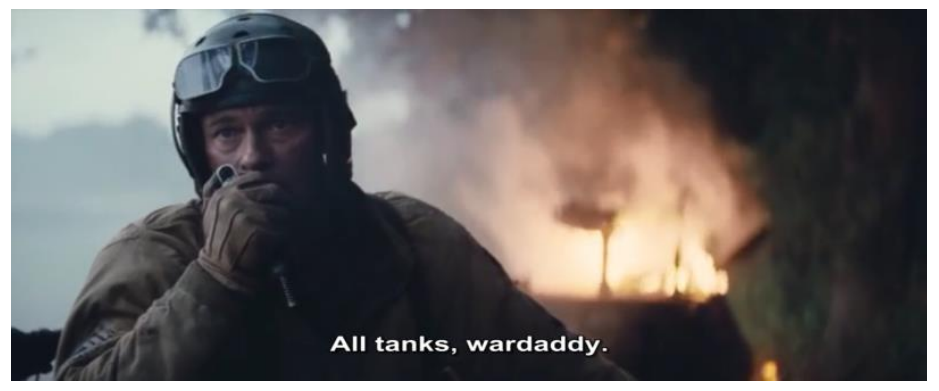

Figure 1. Wardaddy give an instruction to his member (Battlefield, 25:19-26:21)

Wardaddy :"Norman!You cocksucker. Why didn't you take the shoot?"

Norman : : "He was just a kid. I'm sorry.I'm really sorry,sergeant."

Wardaddy : "You see what a kid can do?Look!That's your fault. That's your fucking fault. Next German you see with a weapon, you rake the dog shit out of him.I don't care if it's a baby with a butter knife in one hand, and mama's titty in the other.You chop him up!"

Norman : : "Yes, sergeant!"

Wardaddy : "Bible?"

Bible : "Yeah?"

Wardaddy : "all tanks. It's Wardaddy. Looks like I'm it.I'll lead the coloumn. Let's get us where we're going."

The dialogue above shows Wardaddy leads all tanks to the base camp. Because the first leader in their team was death shot by German army just because the norman did not want to shoot the little boy from German. After that, Wardaddy resented Norman's unprofessional attitude at work and forced Norman's will to shoot the Germans regardless of gender or anything and eventually Wardaddy taught Norman how to shoot at the German army without hesitation. This below are another scene shows wardaddy is a leader of the team.

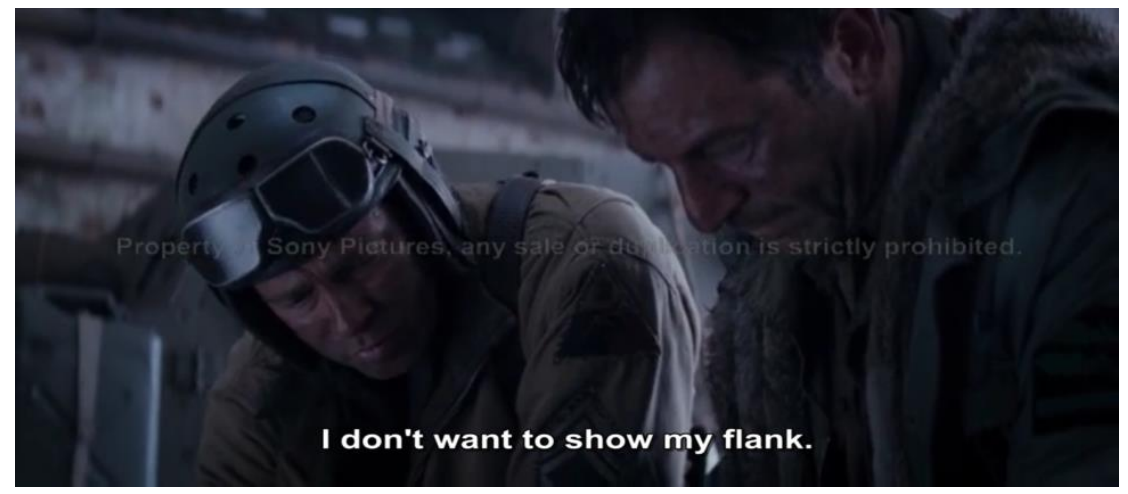

Figure 2. Wardaddy and old man arrange a strategy

(Army post,28:12-28:44) 


\begin{abstract}
Wardaddy :" This high ground, you got any eyes on it?"
Old man : : "I had eyes there, gone. There, gone. We're flying blind. It's you and me."

Wardaddy : :Krauts got sights on this road.I don't want to show my flank.Any objectjon if I come in here?"

Old man : : "You can arrive on a fucking magic carpet, for all I care.I know who you are. I know you know what you're doing.You just paste them hard for me.They murdered some good boys out there today. Why dont they just quit?"

Wardaddy : "Would you?"

The dialogue above shows old man makes a strategy for safe the other member of tanks. but Wardaddy make their own strategy to safe the member because as leader, he can already predict what will happen and he can make decisions quickly. In the end, Wardaddy has his own strategy and way of dealing with Nazi German soldiers and the old man is paying close attention to Wardaddy's strategy and the old man agrees with the plan Wardaddy has made because the most important thing for the elderly man is that all the tank members can survive against the Nazis German.
\end{abstract}

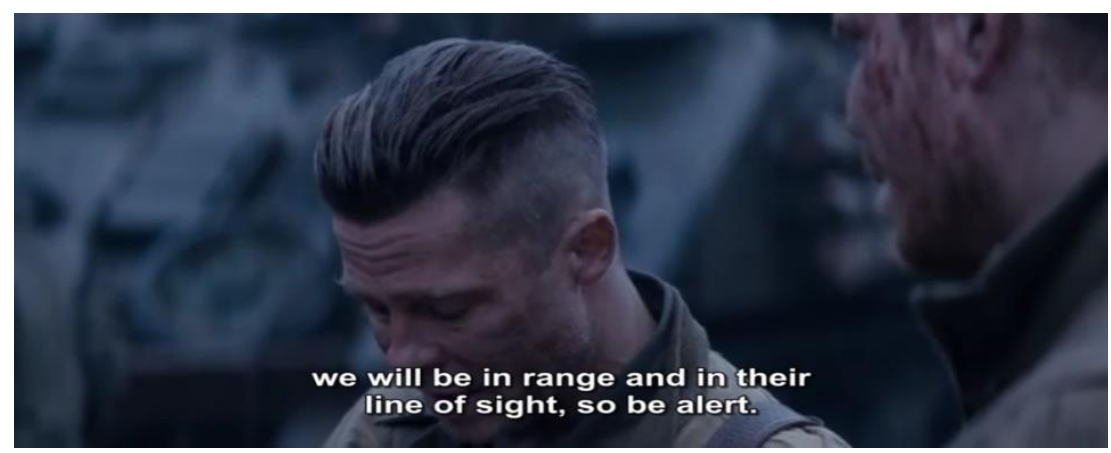

Figure 3. Wardaddy tell to Davis about the strategy

(Armypost,28:46- 29:06)

Wardaddy : :'We got a platoon pinned down in this field by mgs.

Krauts got anti-tank covering the field.

And once we cross this hedgerow, we will be in range ang in their line of sight, so be alert.Hit anything fucking moves."

Davis : " "Yeah, unless they pound us first."

Wardaddy :"'If they do, we'll know exactly where they are.

Let's get this boy out of there and smash those guns.

Then we'll capture the town, stop for the night. Clear?" 
The dialogue shows Wardaddy as the leader of the tank forces responsible for protecting his team by telling other teams about the strategy against enemies so that they can act immediately according to the existing plan so that when Nazi German soldiers are present they can take action without hesitation, and they can be careful and alert to any enemy movement.

\section{Types of the Leadership Shows in the Main Character}

The theory used in types of the leadership is the theory of Veliu et al (2017) in this movie. After analysis this movie, the writer founded 2 types of leadership there are:

\section{Autocratic style}

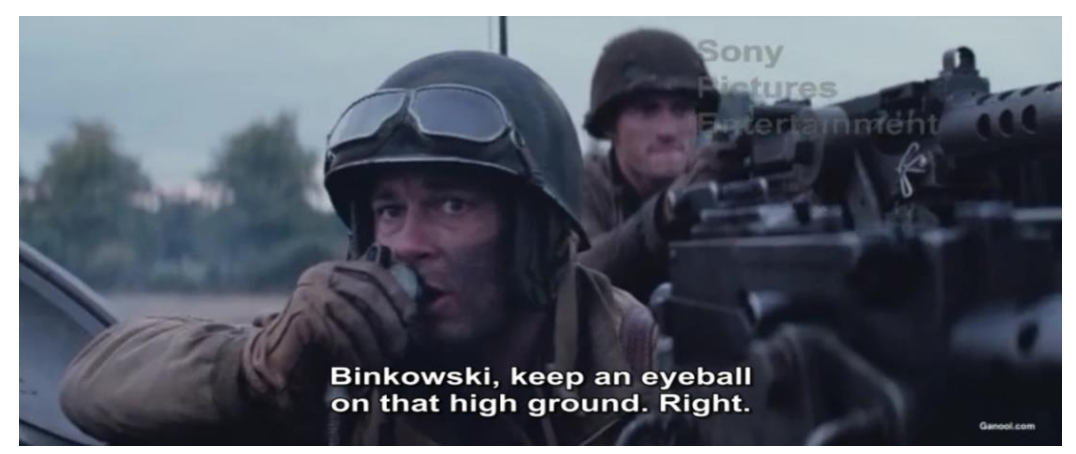

Figure 4. Wardaddy giving orders for Binkowski to be wary of enemies

(Battlefiled, 30:50-31:07)
Wardaddy : "Binkowski, keep an eyeball on that high ground. Right."
Binkowski : "Love 1-5 copies.Wilco."
Wardaddy :"Watch that tree line right there.Hold that, hold that.
Ride on, ride on. Hold tight.We'regonna bust through this shit.All right, here we go, men."

The dialogue above shows as a leader, Wardaddy should be able to give direction like an autocratic style in which the leader must be able to give direction or command quickly and the command must be obeyed by his team without hesitation. Visible, Wardaddy is giving instructions to his team members in tracing the Nazi German army and he asks his team to remain focused in carrying out its mission so that everything goes according to the plan and all teams can be saved. 


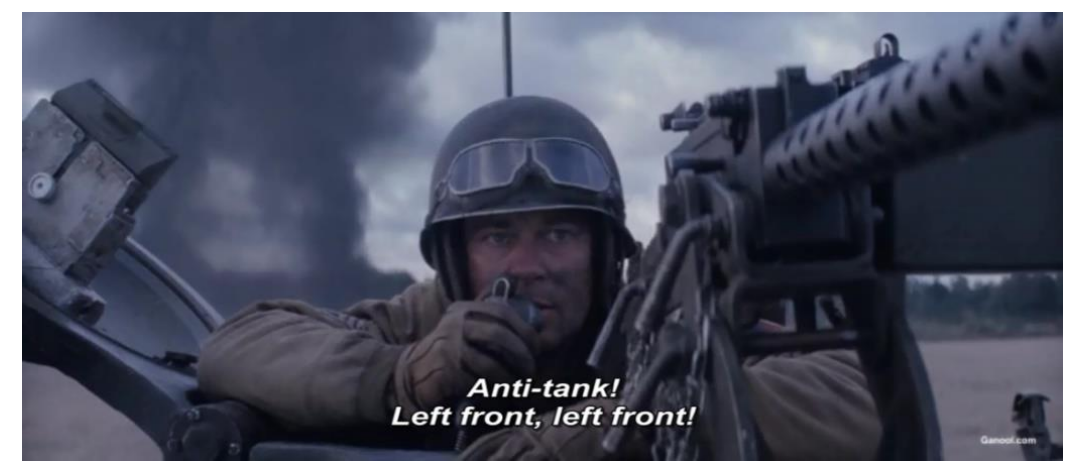

Figure 5. Wardaddy tell to other tank about Nazi German have an Anti-tank

(Battlefield, 32:55-33:04)

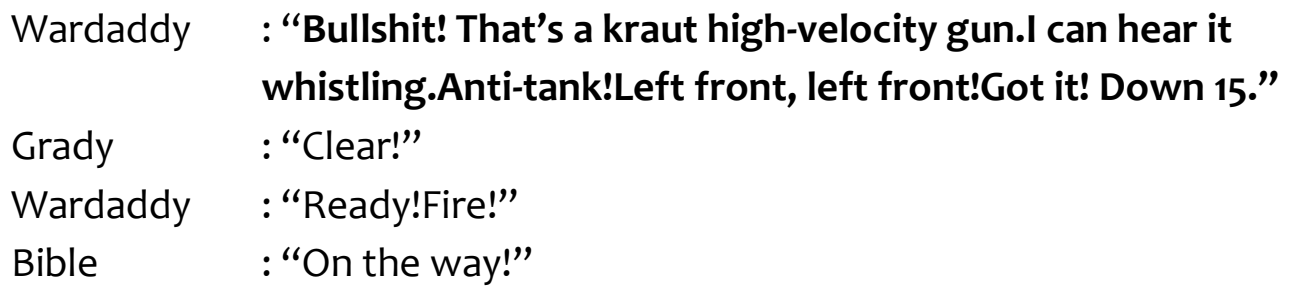

The dialogue shows Wardaddy telling his troops that there is an anti-tank in front of them and they must quickly destroy the anti-tank. Wardaddy hinted at his team, Graddy and Bible, to prepare weapons to quickly destroy the anti-tanks without hesitation. Because if not immediately destroyed, the anti-tank is very dangerous for all troops tank led by Wardaddy so that if the anti-tank is not immediately destroyed, it will make a plan that has been made into a mess.

\section{Bureaucratic Style}

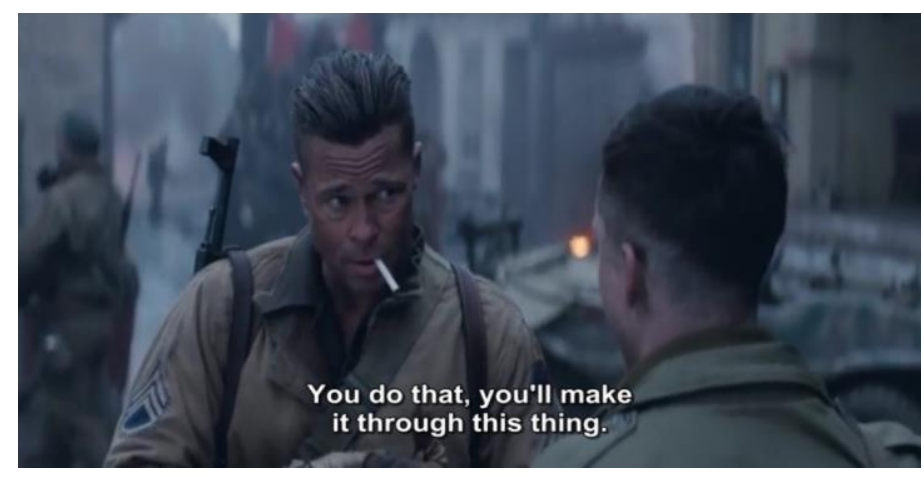

Figure 6. Wardaddy tell to Norman that he must follow the Wardaddy's rules

(German town,52:10-53:27)

Wardaddy : "I want to show you some thing.They knew we were coming. So they got drunk as lords. And they shot themselves at sunup."

Norman : : "Why are you showing me this?"

Wardaddy : "Ideals are peaceful.History is violent. Do what I tell you. You do that, you'll make it through this thing. Come on." 
The dialogue shows that as a leader, Wardaddy tells Norman that Norman must obey and follow what Wardaddy instructs that all goes well and all the tanks survive. Because anything that Wardaddy has commanded as a leader is an obligation that his entire team has to undertake without exception. Team forces must obey all rules that Wardaddy has set for all plans to work properly.

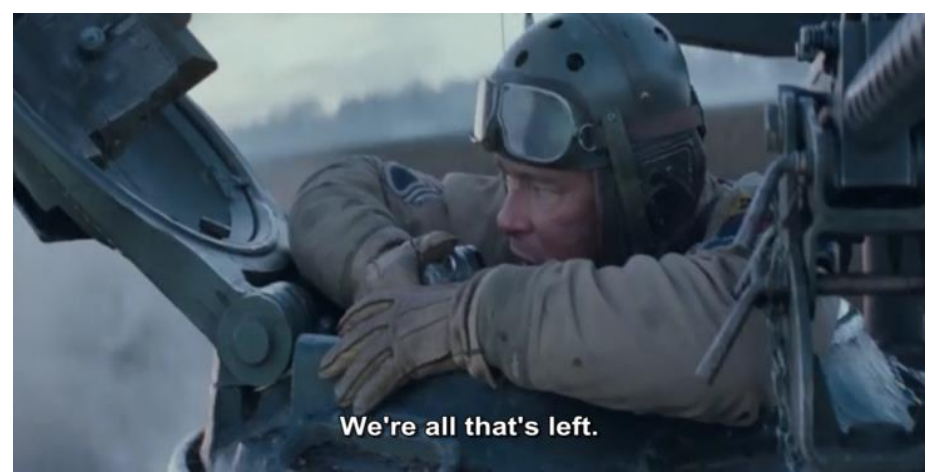

Figure 7. Wardaddy and his members survive from battlefield (Battlefield, 01:22:18-01:22:35)

Wardaddy : : "Roy's gone.We're all that's left.lt's up to us now.

Nazi's soldier: Driver halt!"

Wardaddy : "Gordo, get around him.Put us on his backside.

If we get behind him, we can kill him.Go! Go! Go!"

Nazi's soldier : "Reverse reverse!Don't let him behind us!”

Wardaddy : "Faster, Gordo!"

The above dialogue shows Wardaddy telling Gordo to look for the weaknesses of the Nazi tanks because according to Wardaddy if he knows the weakness of the Nazi German tanks, he can immediately know what to do to destroy the Nazi German tanks in accordance with the plans he has made. So that the entire team of tank troops can also survive the battle that exists.

\section{The Moral Message in Fury Movie}

A moral message is a message that is conveyed or a lesson to be learned from a story or event. A moral message in Fury movie is attitude of the leader and the member in facing the problem in the war world. There are some moral message as follows: 
1. Virtue

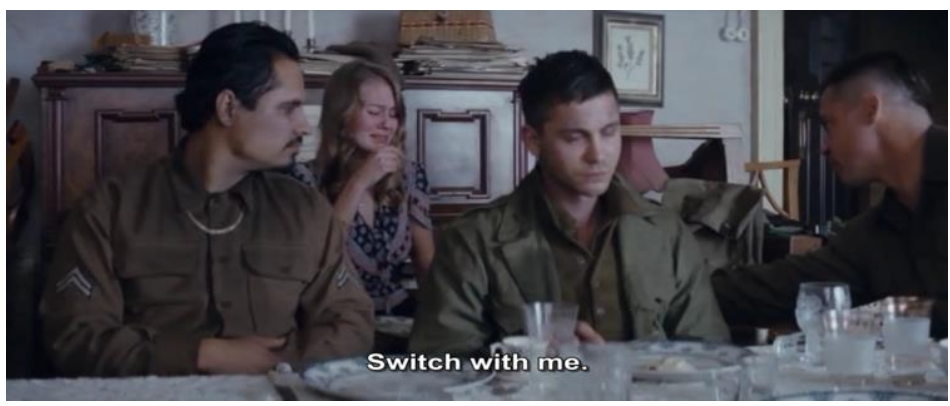

Figure 8. Wardaddy switch the girl's food that licked by Grady

(House of german woman,01:08:52-01:09:07)

Grady : : "Hang on, there. I'm gonna fix that for you.

Let me just fix this for you real quick.

I didn't touch her."

Wardaddy : "Switch with me."

First is virtue. Based on that scene, Wardaddy has a high moral ethic even though he kills German Nazi soldiers but he treats German women with love and respect that is proved by Wardaddy willingly defending a German woman with a form of virtue by the way he is willing to exchange the food of a German lady who has been licked by Grady with his food. The Wardaddy also showed his respect by not touching or being rude to the German woman that he really keep the honor of the German women when as an American soldier, he really hates all the Germans but the two German women are not among the Germans who hated Wardaddy.

2. Sacrifice

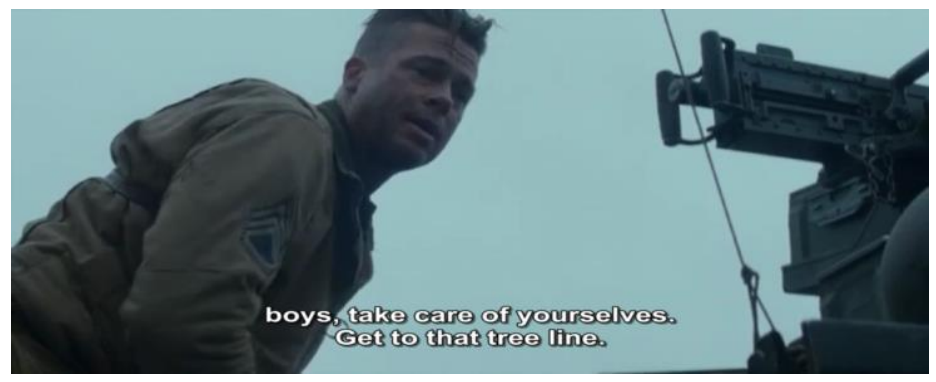

Figure 9. Wardaddy ask to all member for safe theirself from German Soldier

(Crossroad,01:34:17-01:34:39)

Wardaddy : : "Get out of here. Boys, take care of yourselves. Get to that tree line. It's all right."

Bible : : "Hmm. It's all right."

Wardaddy : "It's my home."

Second is sacrifice. Although Wardaddy is a cruel leader for his team but he as a leader willing to sacrifice for the safety of his team by having them hide from 
the German army because Wardaddy and his team have seen from a distance that there will be a German Nazi soldier who will pass his tank and he immediately ordered his team to let Wardaddy stay in the Fury tank to face the Germans alone because for Wardaddy, the Fury tank is home to him so he will not leave his tank whatever happens.

3. Religious Man

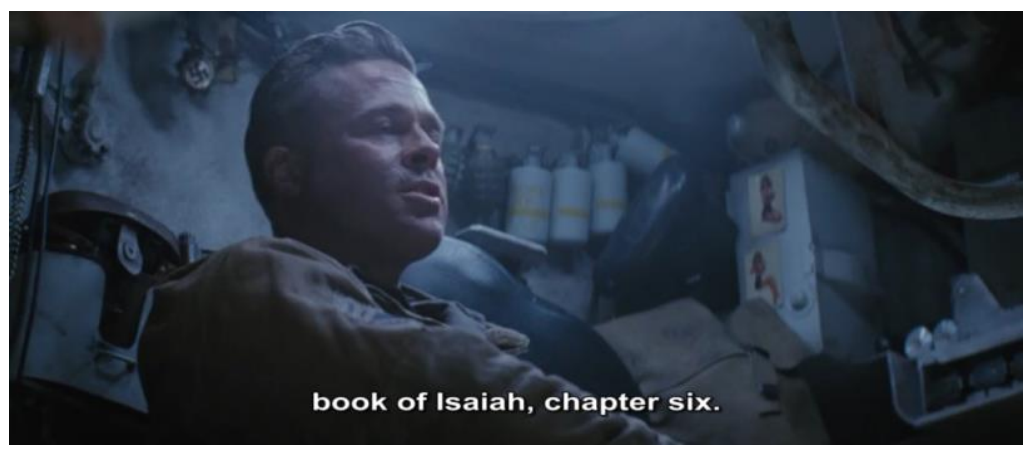

Figure 10. Wardaddy and his member remember to God (In Tanks,01:39:13-01:40:19)

Bible : "You know, there's a Bible verse I think about sometimes. Many times. It goes... "Then I heard the voice of the lord saying Whom shall I send? And who will go for us? "And I said, Here am I. Send me."

Norman : "Send me."

Wardaddy : "Book of Isaiah, chapter six."

Bible : Y Yeah. Yeah, Don. That's exactly right. You're something."

The last is religious man, reference to Jesus is abundant in this movie. although this film tells of a war that features many murders there is a religious moral message that is always quoted from Wardaddy and his team when they feel fear and anxiety in the face of their enemies. Even when they are all trapped in tanks when there is an enemy, they are all resigned to die together, they feel sad and afraid of the situation and suddenly they mention a verse of the Book Bible to calm their minds and hearts at that moment.

\section{CONCLUSION}

There are two types of leadership style that are autocratic and bureaucratic leadership style in this movie. Leadership in this movie based on some phrases and actions performed by the main actor or outside of the main character. The autocratic leadership style found in this movie based on the strong determination and courage of the main cast to take a quick decision making and give orders and expect the team member to be obeyed without hesitation. While bureaucratic leadership style in this movie based on the characteristic of the main cast is strict 
implementation of procedures and leader make rigid rules-based decisions without flexibility. The leader sets all standards on how the team member performs the task to achieve their goals.

The moral message also contained in the movie that is a virtue, sacrifice, and religious man. The virtue in this movie shows when the leader Wardaddy has a high moral ethic even though he kills German Nazi soldiers but he treats German women with love and respect. While for the sacrifice in this movie shows when Wardaddy, as a leader, willingly sacrificed for the safety of his team by telling them to hide from the German army and ordering them to let Wardaddy remain in the Fury tank to face the German army alone. Although in this movie, Wardaddy and the team member were a fairly cruel but they still remember and pray to God through the reference of Jesus when they feel fear in the face of the Nazi German.

\section{REFERENCES}

Achua, \& Lussier. (2010). Effective Leadership. Canada: Cengage Learning.

Anisti. (2017). Komunikasi Media Film Wonderful Life. Journal AKOM BSI Jakarta. Vol VIII ,No.1. Page 33-39.

Feriyanto, Andri and Endang Shyta Triana. (2015). Pengantar Manajemen. Jakarta: Mediatera.

Hao, Moo Jun and Rashad, Y. (2015). How Effective Leadership can Facilitate Change in Organizations through Improvement and Innovation. Global Journal of Management and Business. Vol.15 Issue 9. Page 1-6.

Iqbal, Anwar, and Halder. (2015). Effect of Leadership Style on Employee Performance. Arabian Journal of Business and Management Review. 1-6.

Kim, J., Ha, Y., Kang, S., Lim, H., \& Cha, M. (2018, January). Detecting Multiclass Emotions from Labeled Movie Scripts. In 2018 IEEE International Conference on Big Data and Smart Computing (BigComp) (pp. 590-594). IEEE.

Ning, M., \& Xia, S. (2018, August). Research on Patriotism Education Based on New Military Films-Taking the Popular Movie" Red Sea Action" in 2018 as an Example. In 2018 2nd International Conference on Education Science and Economic Management (ICESEM 2018). Atlantis Press.

Semuel, Hatane. Hotlan Siagian and Stefanie Octavia (2017). The Effect of leadership and innovation on differentiation strategy and company performance. Procedia Social and Behavioral Sciences. Page 1152-1159.

Sharma, Dr. Manoj Kumar and Miss Shilpa Jain (2013). Leadership Management: Principles, Models and Theories. Global Journal of Management and Business. Vol.3 No. 3. Page 309-318.

Sugiyono. (2010). Metode Penelitian Kuantitatif, Kualitatif dan R\&D. Bandung: Alfabeta. 
104 Eralingua: Jurnal Pendidikan Bahasa Asing dan Sastra Vol.3, No.2, Agustus 2019

Thorbjørnsen, H., Dahlén, M., \& Lange, F. (2019). Tomorrow never dies: preadvertised sequels boost movie satisfaction and WOM. International Journal of Advertising, 1-12.

Veliu, Liridon, Mimoza Manxhari, Visar Demiri and Liridon Jahaj (2017). The Influence of Leadership styles on Employee's Performance. Journal of Management and Social Science. Vol. 31 No. 2. Page 59-69.

Wallin, B, and Dr. A. Arjunan (2015). Characterisation an Intrinsic Aspect of Dramatic Text. IOSR Journal of Humanities and Social Science.Vol. 20. Page 76-78.

Yastanti, Unpris and Emma Soraya (2016). Schizophrenia of Main Character In Beautiful Mind MovieDirected By Ron Howard. Journal ABA BSI Jakarta. Vol. 8 No. 1. Page 33-45. 